Jörg Mampel · Miguel A. Providenti · Alasdair M. Cook

\title{
Protocatechuate 4,5-dioxygenase from Comamonas testosteroni T-2: biochemical and molecular properties of a new subgroup within class III of extradiol dioxygenases
}

\begin{abstract}
Comamonas testosteroni T-2 degraded at least eight aromatic compounds via protocatechuate (PCA), whose extradiol ring cleavage to 2-hydroxy-4-carboxymuconate semialdehyde (HCMS) was catalysed by PCA 4,5-dioxygenase (PmdAB). This inducible, heteromultimeric enzyme was purified. It contained two subunits, $\alpha(\operatorname{PmdA})$ and $\beta(\mathrm{PmdB})$, and the molecular masses of the denatured proteins were $18 \mathrm{kDa}$ and $31 \mathrm{kDa}$, respectively. PCA was converted stoichiometrically to HCMS with an apparent $K_{\mathrm{m}}$ of $55 \mu \mathrm{M}$ and at a maximum velocity of $1.5 \mu \mathrm{kat}$. Structureactivity-relationship analysis by testing 16 related compounds as substrate for purified PmdAB revealed an absolute requirement for the vicinal diol and for the carboxylate group of PCA. Besides PCA, only 5'hydroxy-PCA (gallate) induced oxygen uptake. The Nterminal amino acid sequence of each subunit was identical to the corresponding sequences in C. testosteroni BR6020, which facilitated sequencing of the pmd $A B$ genes in strain T-2. Small differences in the amino acid sequence had significant effects on enzyme stability. Several homologues of $p m d A B$ were found in sequence databases. Residues involved in substrate binding are highly conserved among the homologues. Their sequences grouped within the class III extradiol dioxygenases. Based on our biochemical and genetic analyses, we propose a new branch of the heteromultimeric enzymes within that class.
\end{abstract}

J. Mampel $(\bowtie) \cdot$ A. M. Cook

Fachbereich Biologie, Universität Konstanz,

78457 Konstanz, Germany

M. A. Providenti

Carleton University, Ottawa,

ONT, KIS5B6, Canada

Present address: J. Mampel

Institut für Mikrobiologie,

Eidgenössische Technische Hochschule Zürich,

8093 Zürich, Switzerland

E-mail: joerg.mampel@micro.biol.ethz.ch

Tel.: + 41-1-6323849

Fax: $+41-1-6321378$
Keywords Extradiol - Oxygenase - Degradation · Toluenesulfonate $\cdot$ Structure-activity relationship

\section{Introduction}

Oxygenases play key roles in aerobic degradation of natural or xenobiotic aromatic compounds by (1) activation (ring hydroxylation) and (2) cleavage of the inherently inert aromatic structure. A broad variety of peripheral pathways channel aromatic substrates to a limited number of central diol intermediates which are further metabolized by enzymes of central pathways, allowing the generation of amphibolic intermediates. For vicinal diols like catechol and protocatechuate (PCA), ring-cleavage dioxygenases catalyse the conversion of aromatic substrates into aliphatic products by intradiol fission of the $\mathrm{C}-\mathrm{C}$ bond (ortho cleavage) or extradiol fission (meta cleavage).

It is generally accepted that extradiol oxygenases are evolutionarily unrelated to intradiol cleavage enzymes (Harayama et al. 1992). Extradiol dioxygenases of classes I and II were first distinguished by biochemical data (Harayama and Rekik 1989). Molecular data showed that class II enzymes, with their two-domain structure, evolved by gene duplication from ancestral, one-domain, class I extradiol enzymes (Eltis and Bolin 1996). In contrast, class III enzymes do not share a common ancestor with enzymes of the other two classes. Their structural fold bears no resemblance to the fold shared by class I and class II enzymes (Sugimoto et al. 1999).

Dagley et al. (1968) cited the widespread importance of the extradiol cleavage of PCA and inferred biodiversity in the extradiol cleavage enzymes (Dagley et al. 1960). PCA is the point of convergence of pathways for degradation of many aromatic compounds, for example $p$-toluenesulfonate in Comamonas testosteroni $\mathrm{T}-2$ (Cook et al. 1999), of $m$-chlorobenzoate in C. testosteroni BR60 (Nakatsu and Wyndham 1995), and of lignin 
in Sphingomonas paucimobilis SYK-6 (Noda et al. 1990; Hara et al. 2003). In these bacteria, PCA is degraded by PCA 4,5-dioxygenase (PmdAB), which is encoded by lig $A B$ in S. paucimobilis SYK-6 and pmdAB in C. testosteroni BR6020 (Providenti et al. 2001). The crystal structure of LigAB from $S$. paucimobilis SYK-6 (Sugimoto et al. 1999) was preliminary evidence that this group of extradiol cleavage enzymes could be attributed to class III; however, there was a need to broaden the available data set to support this notion.

Transport, regulation and the soluble enzymes of the peripheral pathway in the degradation of $p$-toluenesulfonate and $p$-toluenecarboxylate to PCA by $C$. testosteroni $\mathrm{T}-2$ have been explored, and all oxygenases involved were characterized except for PmdAB (Cook et al. 1999; Mampel 2000; Mampel et al. 2004; Tralau et al. 2003a, 2003b). We now present an analysis of this class III oxygenase from $C$. testosteroni $\mathrm{T}-2$ which catalyses the key reaction linking peripheral and central degradative pathways. This work further illustrates biodiversity among class III oxygenases in terms of phylogenetic relationships and biochemical properties, although key features of these enzymes appear highly conserved.

\section{Materials and methods}

Bacteria, growth conditions, harvesting of cells and preparation of heat-treated, cell-free extract

The following strains of $C$. testosteroni were used: the type strain ATCC 11996, BR6020 (Providenti et al. 2001), PSB-4 (DSM 11414) (Thurnheer et al. 1986) and T-2 (DSM 6577) (Thurnheer et al. 1986; Busse et al. 1992). C. testosteroni was grown at $30^{\circ} \mathrm{C}$ in mineral salts medium (Thurnheer et al. 1986; Junker et al. 1996) containing a sole carbon source at $6 \mathrm{mM}$ initial concentration on a 1.5-1 scale, in 5-1 shake flasks at $225 \mathrm{rpm}$. Strain T-2 for enzyme purification was grown at $30^{\circ} \mathrm{C}$ in a 12.5-1 fermenter with a 9-1 working volume (Biostat V, Braun, Melsungen) in $12 \mathrm{mM}$ PCA-salts medium (Thurnheer et al. 1986; Junker et al. 1996). Cells were harvested at $580 \mathrm{mg}$ protein/l (see 'Results') in a Pellikon cassette filtration system (Millipore), washed twice in ice-cold $50 \mathrm{mM}$ potassium phosphate buffer $(\mathrm{pH} 7.5)$ and stored frozen $\left(-20^{\circ} \mathrm{C}\right)$.

Cells (25 g wet weight) were resuspended in $25 \mathrm{ml}$ chilled, freshly prepared $20 \mathrm{mM}$ Tris/HCl buffer (pH 7.5) containing $1 \mathrm{mM}$ dithiothreitol (DTT) and DNase I $(2 \mu \mathrm{g} / \mathrm{ml})$, and disrupted by three passages through a chilled French pressure cell at $135 \mathrm{MPa}$. Phenylmethanesulfonylchloride (to $1 \mathrm{mM}$ ), L-cysteine (to $1 \mathrm{mM}$ ) and $\mathrm{Fe}\left(\mathrm{NH}_{4}\right)_{2}\left(\mathrm{SO}_{4}\right)_{2}$ (to $50 \mu \mathrm{M}$ ) were added, and whole cells and debris were removed by centrifugation $\left(36,000 \mathrm{~g}, 30 \mathrm{~min}, 4^{\circ} \mathrm{C}\right)$. The stirred supernatant fluid was then brought to $45^{\circ} \mathrm{C}$ for 2 min and immediately chilled in a cryostat. Precipitated proteins and membrane fractions were removed by ultracentrifuga- tion $\left(500,000 \mathrm{~g}, 40 \mathrm{~min}, 4^{\circ} \mathrm{C}\right)$. The supernatant fluid (50$70 \mathrm{mg}$ protein $/ \mathrm{ml})$ was filtered $(0.2-\mu \mathrm{m}$ pore diameter $)$ and could be stored frozen at $-70^{\circ} \mathrm{C}$ for at least 4 weeks, without significant loss of activity.

\section{Enzyme assays}

The activity of PmdAB was assayed routinely at $30^{\circ} \mathrm{C}$ as substrate-dependent oxygen uptake in a Clark-type oxygen electrode (Locher et al. 1991). Reaction mixtures $(0.5 \mathrm{ml})$ contained $40 \mathrm{mM}$ Tris-SO $\mathrm{SO}_{4}(\mathrm{pH} \mathrm{7.5}), 0.5$ $1.5 \mathrm{mg}$ protein and $2.5 \mu \mathrm{mol}$ PCA, with which the reaction was started. Enzyme kinetics were determined by substrate induced oxygen uptake assays. The PCA concentrations applied were $3-600 \mu \mathrm{M} ; K_{\mathrm{m}}$ and $V_{\max }$ values were derived from nonlinear regression analysis of Michaelis-Menten plots, using a two-parameter fitting (SigmaPlot). The resulting equation was $f=a^{*}$ $\left[1-\exp \left(-b^{*} \mathrm{x}\right)\right], a=88.6, b=0.0125 ; R^{2}=0.97$. PmdAB in fractions from column chromatography was detected as the increase in absorbance at $410 \mathrm{~nm}$ at $25^{\circ} \mathrm{C}$, due to the formation of product (Ribbons and Evans 1960). Positive fractions could be detected visually and quantified after $5 \mathrm{~min}$. The 1-ml reaction mixture contained $4 \mathrm{mM}$ PCA in $20 \mathrm{mM}$ Tris $/ \mathrm{SO}_{4}(\mathrm{pH} 7.0)$, and the reaction was started with $50-150 \mu \mathrm{l}$ column eluent.

Screening for PmdAB in differently grown cells

Organisms were grown with different carbon sources, harvested, disrupted, and the supernatant fluid used without further treatment. About $80 \mathrm{mg}$ protein was loaded on to an anion-exchange column (UnoQ, 6-ml bed volume, Bio-Rad) equilibrated with $20 \mathrm{mM}$ Tris/ $\mathrm{SO}_{4}(\mathrm{pH} 7.5$ ) containing $1 \mathrm{mM}$ DTT (buffer A) at $2 \mathrm{ml} /$ min, and fractions of $4.5 \mathrm{ml}$ were collected. The column was washed with buffer $\mathrm{A}$ for $30 \mathrm{~min}$, when a linear gradient to $20 \%$ buffer $\mathrm{B}\left[20 \mathrm{mM}\right.$ Tris $/ \mathrm{SO}_{4}$ (pH 7.5) $1 \mathrm{M} \mathrm{Na}_{2} \mathrm{SO}_{4}, 1 \mathrm{mM}$ DTT] was applied for $63 \mathrm{~min}$ and then ramped to $100 \% \mathrm{~B}$ in $10 \mathrm{~min}$. Each fraction was assayed visually for the presence of PmdAB as an increase in absorbance at $410 \mathrm{~nm}$. Activity was confirmed and quantified as PCA-dependent oxygen uptake. Proteins in the fractions with the highest specific activity were separated by sodium dodecyl sulphate-polyacrylamide gel electrophoresis (SDS-PAGE).

\section{Purification of PmdAB}

A three-step chromatographic procedure was used, which was carried out in one day. Fractions containing significant activity were combined, and the protein in this solution was desalted and concentrated by membrane filtration (30-kDa exclusion limit, Diaflo, Amicon) in a stirring cell (model 8050, Amicon). The desalting buffer was $10 \mathrm{mM}$ Tris $/ \mathrm{SO}_{4}$ buffer containing $1 \mathrm{mM}$ 
DTT, $2 \mathrm{mM}$ L-cysteine, $50 \mu \mathrm{M} \mathrm{Fe}\left(\mathrm{NH}_{4}\right)_{2}\left(\mathrm{SO}_{4}\right)_{2}, 5 \%$ (v/ v) glycerol and $2.5 \mathrm{mM}$ ascorbate and adjusted to $\mathrm{pH}$ 7.5. All mobile phases were freshly prepared and degassed in an ultrasonic bath before oxidation-sensitive ingredients were added. Mobile phases included $1 \mathrm{mM}$ DTT, $2 \mathrm{mM}$ L-cysteine, $50 \mu \mathrm{M} \mathrm{Fe}\left(\mathrm{NH}_{4}\right)_{2}\left(\mathrm{SO}_{4}\right)_{2}$ and $5 \%$ $(\mathrm{v} / \mathrm{v})$ glycerol. They were degassed and subsequently protected against atmospheric oxygen by a blanket of argon. Fast protein liquid chromatography was done at room temperature with a Pharmacia apparatus. Samples for flash freezing in liquid nitrogen contained glycerol $(20 \% \mathrm{v} / \mathrm{v})$; they were stored at $-70^{\circ} \mathrm{C}$. The three-step chromatographic procedure proceeded as follows:

1. Heat-treated extract (about $500 \mathrm{mg}$ protein) was loaded on the DEAE-column $(300 \times 26 \mathrm{~mm}$, DEAESepharose CL-6B, Pharmacia), which was run with supplemented (see above) Tris-buffered eluents (pH 7.5), as described elsewhere (Junker et al. 1994b). The fraction size was $5 \mathrm{ml}$, and the enzyme eluted between $275 \mathrm{ml}$ and $315 \mathrm{ml}$.

2. Gel filtration chromatography was done with a Superformance cartridge $(600 \times 10 \mathrm{~mm}$, Merck) filled with Superdex 200 prep grade material (Pharmacia). The flow rate was $0.8 \mathrm{ml} / \mathrm{min}$ of supplemented $50 \mathrm{mM}$ Tris $/ \mathrm{SO}_{4}$ buffer ( $\mathrm{pH} 7.5$ ) containing $150 \mathrm{mM}$ $\mathrm{NaCl}$. Activity-containing fractions (fraction size $0.8 \mathrm{ml}$ ) eluted between $22 \mathrm{ml}$ and $25 \mathrm{ml}$.

3. A commercial anion exchange column (Resource Q, 1-ml bed volume; Pharmacia) was equilibrated with supplemented $20 \mathrm{mM}$ Tris $/ \mathrm{SO}_{4}(\mathrm{pH} 7.5)$ at a flow rate of $1 \mathrm{ml} / \mathrm{min}$. The fraction size was $0.5 \mathrm{ml}$. The sample was loaded and the column rinsed for $5 \mathrm{~min}$ before a linear gradient to $10 \%$ high-ionic-strength buffer [supplemented $20 \mathrm{mM}$ Tris $/ \mathrm{SO}_{4}(\mathrm{pH} 7.5) 1 \mathrm{M}$ $\mathrm{Na}_{2} \mathrm{SO}_{4}$ ] was applied over the next $2 \mathrm{~min}$. The gradient was then raised to $20 \%$ high-ionic-strength buffer in $5 \mathrm{~min}$ and finally increased to $100 \%$ highionic-strength buffer in $5 \mathrm{~min}$. The enzyme eluted between $11 \mathrm{~min}$ and $13.5 \mathrm{~min}$.

\section{Analytical methods}

Growth was estimated as turbidity (optical density at $580 \mathrm{~nm}$ ) and quantified as protein in a Lowry-type reaction after solublizing the bacteria (Kennedy and Fewson 1968). PCA and 2-hydroxy-4-carboxymuconate semialdehyde (HCMS) were separated by reversedphase high-performance liquid chromatography (HPLC) (Locher et al. 1989; Laue et al. 1996). Protein was routinely determined by the method of Bradford (Bradford 1976), with bovine serum albumin as standard. The molecular mass of native PmdAB was assayed by gel-filtration chromatography on a Superose 12 column (Pharmacia) with the mobile phase described in step 2 of the gel filtration chromatography procedure (see above) at a flow rate of $0.4 \mathrm{ml} / \mathrm{min}$; standard proteins are described elsewhere (Locher et al. 1991). SDS-
PAGE was done with $12 \%$ separative gels (Schägger and von Jagow 1987), and proteins were stained with colloidal Coomassie Brilliant Blue G-250 (Neuhoff et al. 1988); a 10-kDa Protein Ladder (Gibco) was used for calibration. Proteins were subject to blotting and Nterminal sequencing, as described elsewhere (Laue and Cook 2000).

Polymerase chain reaction (PCR), reverse transcriptase-PCR, DNA sequencing and sequence analysis

PCR quantification of DNA and cycle sequencing was done as described elsewhere (Laue et al. 2001; Tralau et al. 2001). Reverse transcriptase (RT)-PCR of $p$-toluenesulfonate- and PCA-grown cells was essentially done as described by Tralau et al. (2003a). Oligonucleotides to sequence pmd $A B$ in $C$. testosteroni $\mathrm{T}-2$ by primer walking were derived from the nucleotide sequence of the pmd locus in C. testosteroni BR6020 (AF305325; Providenti et al. 2001). The following primers were used to detect by PCR $p m d A, p m d B$ and $p m d A B$ in different organisms: pmdA30 (5'-GCCCGGCACCATCATTTT-3'), pmdA428 (5'-AGTTGCCTTCCTGGTTCTGGT-3'), pmdB5830 (5'-TCTCGCGCCAGTGGATGAAGGACAACAA-3') and pmdB6450 (5'-GCACCACGCGCAATCAGCCACATCAC-3'). Oligonucleotide pmdB6450 was the primer for reverse transcription of mRNA for $p m d B$, and primer pair pmdB5830/pmdB6450 was used for subsequent PCR amplification of cDNA. Primer pairs, annealing temperature and PCR-product length were as follows:

- Amplification of $p m d A$ : pmdA 30 and pmdA $428,54^{\circ} \mathrm{C}$, $421 \mathrm{bp}$

- Amplification of pmdB: pmdB5830 and pmdB6450, $65^{\circ} \mathrm{C}, 648 \mathrm{bp}$.

- Amplification of pmdAB: pmdA30 and pmdB6450, $54^{\circ} \mathrm{C}, 1,187 \mathrm{bp}$.

Sequence data were analysed using standard software (Edit View from PerkinElmer and DNAStar package from Lasergene). Database searches were done with BLAST (Altschul et al. 1997). Multiple sequence alignments were generated by the Clustal X program (Jeanmougin et al. 1998). Relative phylogenetic distances were estimated and visualized using the Megalign program (Clustal method) of the DNAStar package and the Markov program of Saccone et al. (1990, 1993); the latter was also used to estimate the phylogenetic branch points during common evolution of extradiol oxygenases.

Nucleotide sequence accession number

The nucleotide sequence reported in this study has been deposited to the GenBank DNA database under accession no. AF459635. 


\section{Results}

Basal expression and induction of a single PmdAB during growth of $C$. testosteroni strains with aromatic compounds

Extracts of succinate-grown cells of $C$. testosteroni $\mathrm{T}-2$ contained a basal level of PmdAB (Table 1), some 5$10 \%$ of the activity found in induced cells, which contained the enzyme at $2.2-5.5 \mathrm{mkat} / \mathrm{kg}$ protein (Table 1 ). The chromatographic properties of the enzyme from each extract on an ion exchange column were essentially identical (Table 1), so we believe that the same gene products were assayed in each case, as predicted from

Table 1 Activity of protocatechuate 4,5-dioxygenase (PmdAB) in crude extracts of Comamonas testosteroni strains grown with different sources of carbon and energy, and elution of the enzyme from an anion exchange column

\begin{tabular}{llll}
\hline Strain & Carbon source & $\begin{array}{l}\text { Specific activity } \\
\text { (mkat/kg protein) }\end{array}$ & $\begin{array}{l}\text { Active } \\
\text { fraction }\end{array}$ \\
\hline T-2 & Succinate & 0.2 & 33 \\
T-2 & Protocatechuate & 2.5 & 33 \\
T-2 & p-Toluenesulfonate & 2.7 & 33 \\
T-2 & p-Toluenecaboxylate & 2.5 & 33 \\
T-2 & Terephthalate & 5.5 & 35 \\
T-2 & p-Sulfobenzoate & 4.3 & 36 \\
T-2 & p-Anisate & 2.2 & 36 \\
T-2 & Vanillate & 3.8 & 35 \\
T-2 & Phthalate & 3.6 & 34 \\
PSB-4 & Protocatechuate & 2.2 & 34 \\
ATCC 11996 & Protocatechuate & 4.3 & 34 \\
\hline
\end{tabular}

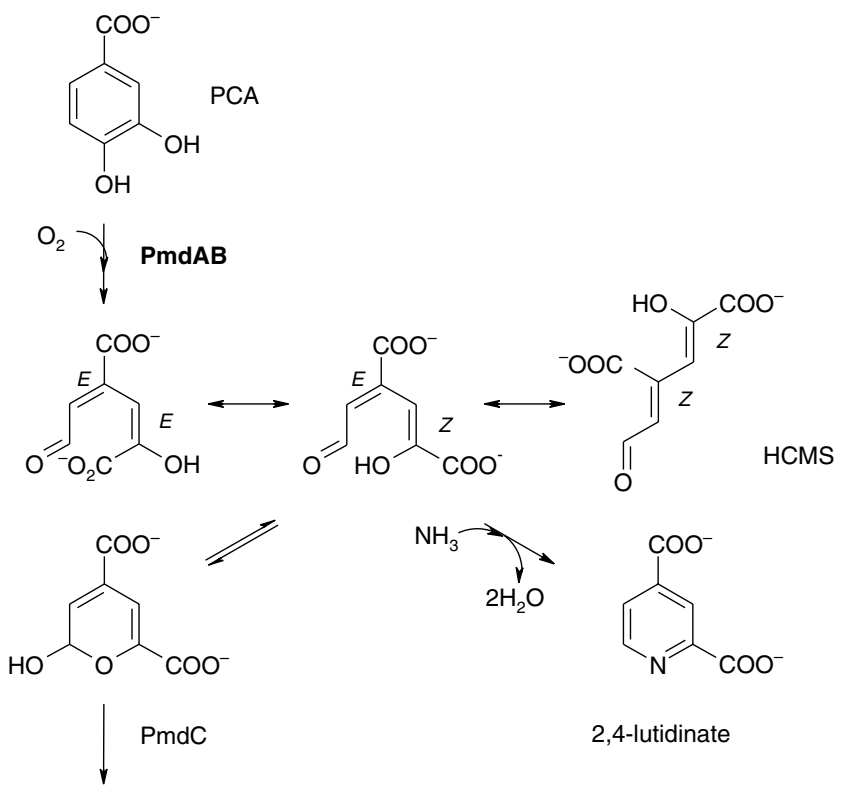

Fig. 1 The reaction of protocatechuate 4,5-dioxygenase (PmdAB) and the nonenzymic reactions leading to the next step in the pathway $(P m d C)$ or nonenzymic formation of lutidinate genetic evidence for a single set of $p m d A B$ genes from a different strain of $C$. testosteroni (Providenti et al. 2001). The active fraction from each chromatogram was subject to SDS-PAGE (not shown), and each sample contained bands corresponding to the $\alpha$ and $\beta$ subunits of the enzyme (see below). The enzyme from two other strains of $C$. testosteroni had the same chromatographic properties as PmdAB (Table 1), the predicted subunits (SDS-PAGE; not shown), and tested positive by PCR for the presence of $p m d A$ and $p m d B$.

PmdAB from strain T-2 converted PCA to a yellow compound, which Locher et al. (1989) tentatively identified as HCMS (Fig. 1); the compound was colourless in acid and had the anticipated UV spectrum (cf. Dagley et al. 1960). We confirmed the identification by allowing HCMS to react with ammonium ion and form 2,4-lutidinate, which was confirmed by co-chromatography (HPLC) and identical UV spectra $\left(\lambda_{\max }, 207\right.$ and $283 \mathrm{~nm}$; shoulder, $227 \mathrm{~nm}$; $\lambda_{\min }, 252 \mathrm{~nm}$ ) (cf. Dagley et al. 1960).

Specific activity of PmdAB in C. testosteroni T-2 as a function of the growth phase

The growth yield of strain T-2 was a linear function of the substrate concentrations up to at least $12 \mathrm{mM}$ PCA, the concentration which was used routinely. The maximum specific growth rate was $0.31 / \mathrm{h}$ (Fig. 2), and growth was concomitant with substrate utilization; correspondingly, no degradative intermediates were detected in the growth medium. The molar growth yield was $5.2 \mathrm{~g}$ protein $/ \mathrm{mol}$ carbon, a normal value corresponding to complete dissimilation of the substrate (Cook 1987).

The specific activity of PmdAB varied widely during growth (Fig. 2). The enzyme was not detectable at the start of the experiment, but activity rose steadily to

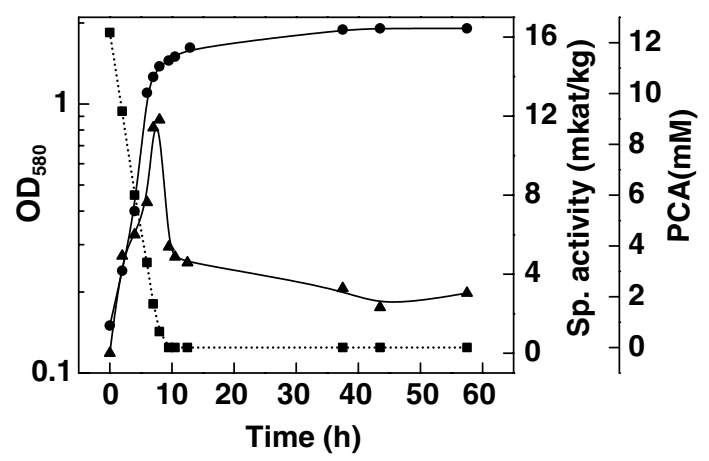

Fig. 2 Growth, substrate utilization and specific activity of PmdAB during growth of $C$. testosteroni $\mathrm{T}-2$ in $12 \mathrm{mM}$ protocatechuate $(P C A)$-salts medium. The inoculum was taken from an exponentially growing culture in PCA-salts medium. Growth (filled circles) was assayed as turbidity. The specific activity (mkat $/ \mathrm{kg}$ protein) of the enzyme in whole cells (filled triangles) was the PCA-dependent oxygen uptake. Substrate concentration (filled squares) was determined by high-performance liquid chromatography 
$12 \mathrm{mkat} / \mathrm{kg}$ protein, when the growth rate was decreasing (about 12 h, Fig. 2), only to fall to about $5 \mathrm{mkat} / \mathrm{kg}$ protein in the stationary phase, where it was effectively stable. Stability of PmdAB activity was independent of ongoing transcription as demonstrated by RT-PCR analysis, which showed the absence of mRNA encoding $p m d B$ in stationary phase. We chose to harvest the cells at a turbidity of $1.1(580 \mathrm{mg}$ protein $/ \mathrm{ml})$, when the specific activity of the enzyme was still rising.

\section{Purification of PmdAB from C. testosteroni T-2}

We attempted to purify PmdAB, using essentially the protocol for C. testosteroni Pt-L5 (Arciero et al. 1983), but after the heat treatment, which yielded a purification (Table 2), hydrophobic interaction chromatography (Phenyl Superose HR) and anion exchange chromatography (UnoQ) caused complete loss of activity. We then supplemented the mobile phases with glycerol, three reducing agents and $\mathrm{Fe}^{2+}$, and protected solutions from atmospheric oxygen under a blanket of argon. We chose DEAE-Sepharose and Superdex 200 material for the first two chromatographic steps and involved a strongly interacting column (ResourceQ) for the final step only (Spence et al. 1996). Freezing and thawing were avoided to prevent precipitation of protein; further steps led to loss of activity. We were thus able to purify the labile enzyme to over $80 \%$ purity, judged by densitometric analysis of SDS-PAGE electropherograms (Fig. 3). This was a 184-fold purification with a final yield of $5 \%$ (Table 2). PmdAB thus represents a very small proportion of soluble cell protein $(0.05 \%)$.

Physical properties of PmdAB from C. testosteroni T-2

The enzyme was presumed to contain two subunits, $\alpha$ (18 kDa, PmdA) and $\beta$ (31 kDa, PmdB), and the preparation contained a significant impurity $(29 \mathrm{kDa}$, Fig. 3, lane 5). The molecular mass of the native enzyme was estimated by gel filtration to be $180 \mathrm{kDa}$. The enzyme was thus a heteromultimer. Due to sequence and structural similarity to LigAB (see below), we suspect that in contrast to LigAB, PmdAB has an $(\alpha \beta)_{4}$ structure.

The N-terminal sequence of PmdA was Ala-Leu-GluLys-Pro-Tyr-Leu-Asp-Val-Pro-Gly-Thr-Ile. The N-terminal sequence of PmdB was Ala-Arg-Ile-Thr-Ala-Ser-

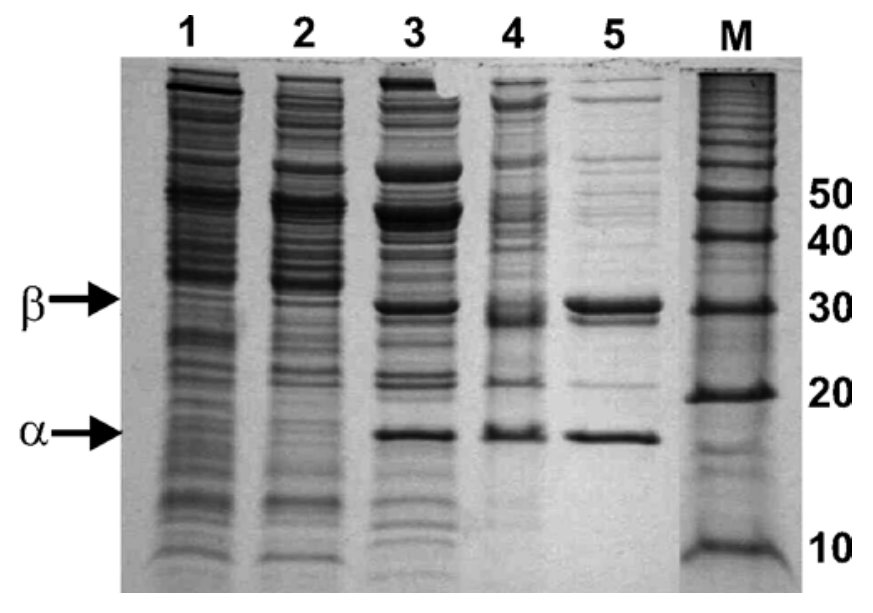

Fig. 3 Purification of PmdAB from C. testosteroni T-2 monitored by sodium dodecyl sulphate-polyacrylamide gel electrophoresis. Protein $(30 \mu \mathrm{g}$, lanes $1-3 ; 15 \mu \mathrm{g}$, lanes 4-6) was separated and subject to staining with Coomassie Brilliant Blue. Lane 1 Crude extract, lane 2, supernatant after heat treatment, lane 3 fraction from anion exchange chromatography, lane 4 fraction from gel filtration, lane 5 fraction from the second anion exchanger, $M$ molecular mass standards (in kilodaltons)

Val-Phe-Thr-Ser-His-Val-Pro. The amino acid sequence of PmdAB in strain T-2 deduced from the gene sequence (see below) includes those obtained by protein microsequencing and show that in each polypeptide, the $\mathrm{N}$ terminal Met was absent from the purified protein. These sequences are identical with those from PmdAB $_{\text {BR6020 }}$ (Providenti et al. 2001).

Catalytic properties of PmdAB from C. testosteroni T-2

The stoichiometry of oxygen required to convert PCA to HCMS was 1:1 when the initial concentration of PCA was $<120 \mu \mathrm{M}$. Above this concentration, the reaction did not go to completion, as has been observed previously (Dagley et al. 1968). We derived values of 55.5 $( \pm 2.3) \mu \mathrm{M}$ PCA and $1.47( \pm 0.3) \mu \mathrm{kat}$ for apparent $K_{\mathrm{m}}$ and $V_{\max }$, respectively; this is close to the value $(46 \mu \mathrm{M})$ for $K_{\mathrm{m}}$ reported for C. testosteroni NCIMB 8893 (Dagley et al. 1968).

We tested the substrate range of PmdAB with structural analogues of PCA: benzoate, 3-hydroxybenzoate, 4hydroxybenzoate, catechol, 3,4-dihydroxybenzaldehyde, 3,4-dihydroxyphenylacetate, 2,3-dihydroxybenzoate,

Table 2 Purification of PmdAB from C. testosteroni T-2

\begin{tabular}{llllll}
\hline Fraction & $\begin{array}{l}\text { Total protein } \\
(\mathrm{mg})\end{array}$ & $\begin{array}{l}\text { Total activity } \\
(\text { nkat) }\end{array}$ & $\begin{array}{l}\text { Specific activity } \\
\text { (mkat/kg protein) }\end{array}$ & $\begin{array}{l}\text { Yield } \\
(\%)\end{array}$ \\
\hline Crude extract & 1,138 & 11.5 & 9 & 100 & 1 \\
Heat treatment & 435 & 10.8 & 25 & 102 & 2.7 \\
DEAE-Sepharose & 21.2 & 2.1 & 99 & 20 & 10.7 \\
Superdex 200 & 5.8 & 5.2 & 894 & 49 & 56.4 \\
Resource Q & 0.3 & 0.5 & 1,709 & 5 \\
\hline
\end{tabular}


3,4,5-trihydroxybenzoate (gallate), 2,4-dihydroxybenzoate, 3,5-dihydroxybenzoate, 2,6-dihydroxybenzoate, gentisate, 3,4-dichlorobenzoate, vanillate and 3,4-diaminobenzoate. Only gallate was a substrate. Thus, the vicinal diol in the 3,4-position and the carboxylate group are essential for activity. In contrast to findings for PmdABs from other sources (Zabinski et al. 1972; Arciero and Lipscomb 1986), none of these nonsubstrates inhibited turnover of PCA, which indicates a high selectivity of the active site in PmdAB in strain T-2. We presume that $\mathrm{PmdAB}_{\mathrm{T}-2}$ will also oxidatively cleave (and dechlorinate) 5-chloroprotocatechuate, as observed elsewhere (Kersten et al. 1985), because the very similar PmdAB $_{\text {BR6020 }}$ (see below) presumably dechlorinates the compound during degradation of 3-chlorobenzoate (Nakatsu et al. 1995).

\section{Sequence of pmdAB from C. testosteroni $\mathrm{T}-2$}

The identical N-terminal amino acid sequences of PmdA and PmdB in strains T-2 and BR6020 (see above) implied high levels of sequence conservation. The corresponding genes are of identical length in each organism, 450 nucleotides for $p m d A$ and 870 nucleotides for $p m d B$, with sequence identities of $91 \%$ and $88 \%$, respectively. There was $99 \%$ identity in the appropriate amino acid sequences (149 and 289 amino acids).

Gene sequences $\left(p m d A B_{\mathrm{T}-2}\right.$, pmd $A B_{\mathrm{BR} 6020}$, proOab, pcm $A, \operatorname{lig} A B, f l d V U$ and $c a r B a b$ ) were subjected to a statistical Markov analysis to estimate the phylogenetic branch points during evolution (Saccone et al. 1990, 1993). Similar analysis of $x y l E$ (Acc. M64747) and nahH (Acc. M17159), which encode class I enzymes, indicate 30 million years of independent evolution (Harayama and Rekik 1993; Hirose et al. 1994). Divergent evolution within the named members of the class III genes was apparently initiated more than 60 million years ago. The same analyses indicate that $p m d B_{\mathrm{T}-2}$ and $p m b B_{\mathrm{BR} 6020}$ have been diverging for about 5 million years, similar to $p m d A_{\mathrm{T}-2}$ and $p m b A_{\mathrm{BR} 6020}$ (4 million years).

\section{Discussion}

The specific growth rate of $C$. testosteroni T-2 with PCA as a substrate $(0.31 \mathrm{~h} / \mathrm{h})$ and the molar growth yield (36 g protein/mol PCA) (Fig. 2) allow a minimum specific activity for the ring-cleavage enzyme to be calculated, $2.4 \mathrm{mkat} / \mathrm{kg}$ protein. The specific activity measured in whole cells (Fig. 2) and in cell extracts (Tables 1,2 ) is higher than this minimum, so it is likely that we have isolated the correct enzyme. The structure of the product of the reaction is routinely presented in the $E, E$ conformation (Fig. 1), but it is presumably present in several conformations (Fig. 1), as are intermediates in the extradiol cleavage pathway of catechol, where the open-chain conformation dominates (e.g.
Junker et al. 1994a). The presence of the bulky carboxylate in HCMS probably reduces the proportion of the molecules in the $Z, Z$ confirmation and metabolism flows through the $Z, E$ confirmation. This may explain why HCMS so readily undergoes the ring-closure reaction with ammonia (via the $Z, E$ conformation), whereas the open-chain pathway product from catechol reacts slowly (Dagley et al. 1960).

Sequence data confirm that enzymes very similar to PmdAB occur in Sphingomonas spp. (Noda et al. 1990; Sugimoto et al. 1999), Pseudomonas straminea (formerly P. ochraceae) (Maruyama et al. 2004), Pseudomonas sp. K82 (Yun et al. 2004), Rhodopseudomonas palustris (Larimer et al. 2004) and in the Gram-positive $A r$ throbacter keyseri (Eaton 2001) (see below). Based on amino acid compositions, we believe that the enzyme from C. testosteroni Pt-L5 (Arciero et al. 1983), from which a definitive picture of the enzyme emerged, is also very similar to PmdAB. However, the similarity did not allow the purification protocol for strain Pt-L5 to be transferred to strain T-2. Likewise, the protocol for strain T-2 was only partially effective for strain BR6020, where only three differences at the amino acid level were detected (D46N and K146A in PmdA, V52I in PmdB). In other systems, a single exchanged amino acid alters the stability of an enzyme (Fersht 1999) or suffices for a PCA 3,4-dioxygenase to cleave 4-sulfocatechol (Contzen et al. 2001), and minor changes in the sequence of dichloromethane dehalogenase alter the $K_{\mathrm{m}}, K_{\text {cat }}$ and $\mathrm{pH}$ optimum (Vuilleumier et al. 2001). We anticipate much microheterogeneity in the PmdAB genes of other strains, given the differences uncovered in this study between $C$. testosteroni T-2 and BR6020 (see above). We believe further that $C$. testosteroni codes for only one Pmd. The same enzyme was present in all the growth conditions we examined in strain T-2 (Table 1). Furthermore, in Southern blot analysis with four strains of C. testosteroni, only one band hybridized (M.A. Providenti, unpublished data), and a knockout of $p m d A$ in strain BR6020 confirmed the absence of an enzyme which could substitute for it (Providenti et al. 2001).

We believed that the specific activity of PmdAB in $C$. testosteroni $\mathrm{T}-2$ was constant during and after growth (Schläfli Oppenberg et al. 1995), which was largely the case when, e.g. $p$-toluenesulfonate was the growth substrate (Mampel 2000). More frequent sampling during growth in PCA-salts medium, however, showed that the level fluctuates markedly (Fig. 2). We wonder if a similar phenomenon is found in other strains of $C$. testosteroni, because Arciero et al. specify precisely when to harvest cells for optimal enzyme purification (Arciero et al. 1983). The phenomenon of the spike of activity was also detected with $p$-toluenesulfonate dioxygenase and $p$ sulfobenzoate dioxygenase (Mampel 2000), where analyses of levels of mRNA encoding these dioxygenases indicated no increase in messenger during the spike. Moreover, mRNA encoding $p$-toluenesulfonate monooxygenase, $p$-sulfobenzoate dioxygenase and $\mathrm{PmdAB}$ was not detected in cells with significant activity in the 


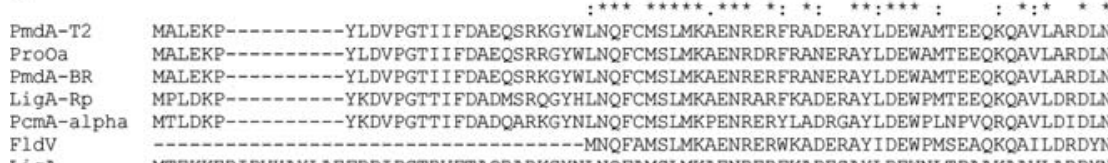

b
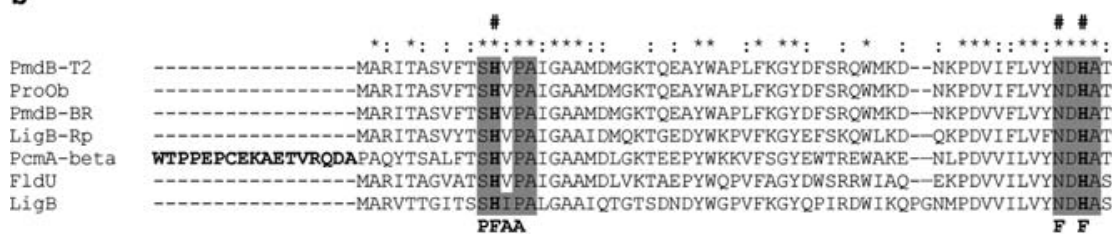

$\#$ MARITASVETSHVPAIGAAMDMGKTOEAYWAPLFKGYDESRQWMKD--NKPDVI FLVY MARITASVFT SHVPAI GAAMDMGKTQEAYWAPLFKGYDFSRQWMKD--NKPDVI FLVY 作 APAQYTSALFT SHVPAIGAAMDLGKTEEPYWKKVESGYEWTREWAKE--NLPDVVILVY MARVTTGITSSHIP LGAAIQTGTSDNDYWGPVFKGYQPIRDWIKQPGMMPDVVILVY

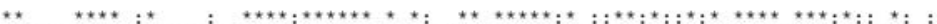

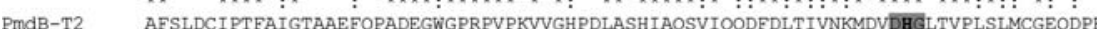
ProOb AFSLDCIPTFAIGTAAEFOPADEGWGPRPVPKVVGHPDLASHIAQSVIQQDFDLTIVNKMDVDHGLTVPLSLMCGEQDPK PmdB-BR AFSLDCIPTFAIGTAAEFQPADEGWGPRPVPKVVGHPDLASHIAQSVIQQDFDLTIVNKMDVDHGLTVPLSLMCGEQDPK LigB-Rp AFSLDLIPTFAIGTAAEYQPADEGWGPRPVPKVIGHPRLAAHIAQSVIQDDFDLTIVNKMDVPHGLTVPLSLMCGEPQ-PcmA-beta AFDSSIIPTFVLGTGAEYPVADEGYGPRPVPDVKGYPELAAHIAQSVIQDDFDLTLVNEMVVDHGLTVPLSLVYGDVE-FIdU AFDMKI I PTFAIGCGERYKPADEGWGPRPVPVVGHADLAWHIAQSLILDEFDMTI INEMDVPHGLTVPMSLMFGQPE-LigB AFDMNIIPTFAIGCAETFKPADEGWGPRPVPDVKGHPDLAWHIAQSLILDEFDMTIMNQMDVDHGCTVPLSMIFGEPE--

PmdB-T2
Proob
PmdB-BR
LigB-Rp
PcmA-beta
FldU
LigB

Fig. 4 Alignments (Clustal $\mathrm{X}$ ) of the $\alpha$ subunits (a) and of the $\beta$ subunits (b) of PmdAB from $C$. testosteroni T-2 with extradiol dioxygenases of $>60 \%$ sequence identity. $\mathrm{PcmA}$ is a monomer, but was considered as two subunits for sequence comparisons; the linker sequence is shown in boldface at the $\mathrm{C}$ terminus of the $\alpha$ subunit and at the $\mathrm{N}$ terminus of the $\beta$ subunit. Histidine residues in boldface are conserved in all class III extradiol oxygenases. Signature sequences for iron ligands observed in crystals of LigAB are indicated by grey boxes within the sequence. Amino acid residues, which interact with the PCA molecule or the mononuclear iron in LigAB, are marked by letters under the sequence: $A$ nonspecific hydrophobic interaction with the aromatic ring of PCA, $F$ coordination of the iron-atom, $P$ specific interaction with

stationary phase. We thus presume that the overall level of oxygenase activity in this organism is controlled not only by transcriptional but also-and presumably more substantially - by post-translational processes.

The deduced amino acid sequences of each subunit of PmdAB $_{\mathrm{T}-2}$ show high levels of identity to annotated extradiol dioxygenases with an $\alpha \beta$-subunit structure. After ProOab and PmdAB ${ }_{\text {BR6020 }}(98-100 \%$ identity to hydroxyl or carboxyl moieties of PCA, asterisks positions with a conserved residue, colons positions with a conservative replacement. In a, crosshatches represent amino acids of the $\alpha$ subunit involved in catalysis; in $\mathbf{b}$, crosshatches represent iron ligands identified for LigB. Data used: PmdAB-T2, (this study) PmdABBR (AF305325, Providenti et al. 2001); ProOab, from Pseudomonas ochraceae (AB127969, Maruyama et al. 2004); PcmA, from Arthrobacter keyseri 12B (AF331043, Eaton 2001); FldVU, putative protein from Sphingomonas sp. LB126 (AJ277295, Wattiau et al. 2001); Lig AB, from S. paucimobilis SYK-6 (M34835, Noda et al. 1990); LigAB-Rp, from Rhodopseudomonas palustris CGA009 (LigA: NP_950035; LigB: NP_950036, Larimer et al. 2004)

the domains corresponding to the $\alpha$ and $\beta$ subunits, respectively, of PmdAB) and LigAB from Rhodopseudomonas palustris $(81-84 \%)$, the highest identity is to monomeric PcmA of A. keyseri $12 \mathrm{~B}$ (71 and $66 \%$ identity), followed by LigAB of $S$. paucimobilis SYK-6 (67 and 60\%) and FldVU, a putative PmdAB of Sphingomonas sp. LB126 (66 and 65\%). There was a clear cutoff to other sequences in databases $(65 \%)$; the 

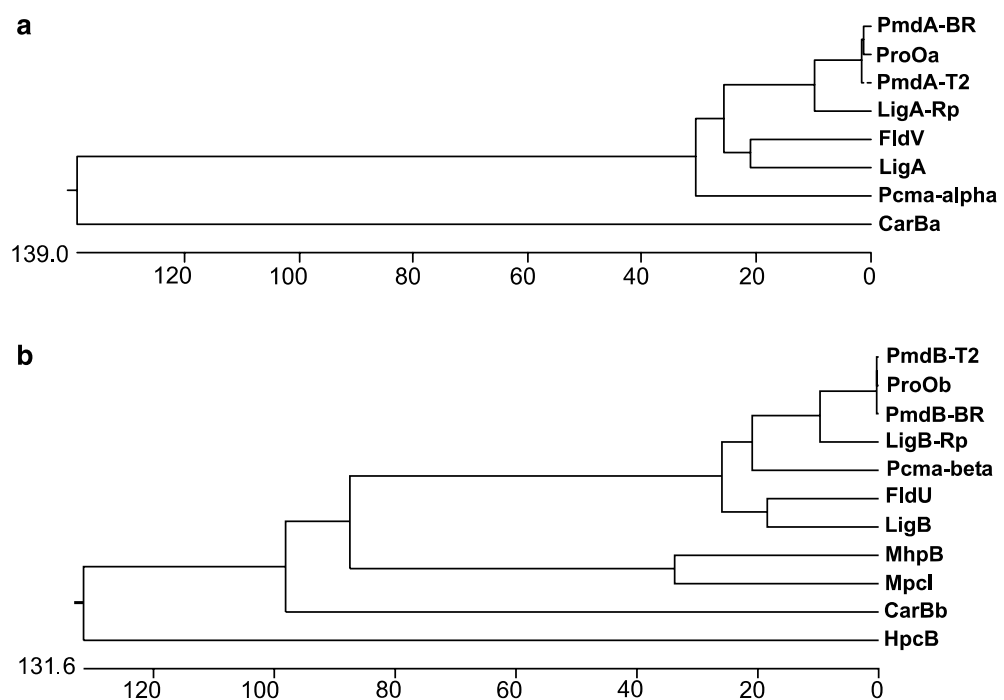

Fig. 5 Balanced dendrograms of $\alpha$ subunits of heteromeric class III extradiol oxygenases (a) or $\beta$ subunits of class III extradiol oxygenases (b). Complete amino acid sequences were aligned using the Clustal method of the DNAStar program Megalign prior to generating the dendrogram; the PAM250 residue weight table was used. The length of the branches indicate relative phylogenetic distances between the individual sequences, so related oxygenases are clustered (accession numbers for sequences are given in brackets): PmdAB, C. testosteroni T-2 or BR6020, PmdAB (AF459635, AF305325); ProOab, P. ochraceae PCA 4,5-dioxygenase (PCA-DO) (AB127969); PcmA, A. keyseri 12B, PCA-DO (AJ277295); FldUV, Sphingomonas sp. strain LB 126, putative PCA-DO, (AJ277295); LigAB, S. paucimobilis SYK-6, PCA-DO; LigAB-Rp, R. palustris CGA009, PCA-DO; CarBab, Pseudomonas sp. CA10, 2-aminobiphenyl 2,3-diol-1,2-dioxygenase (D89064); MhpB, Escherichia coli, 2,3-dihydroxyphenylpropionate dioxygenase (D86239); MpcI, Ralstonia eutrophus JMP222, 2,3-dihydroxyphenylpropionate dioxygenase (X52414); HpcB, E. coli, homoprotocatechuate dioxygenase (Q05353)

next highest level of identity $(28 \%)$ is for CarBab, 2aminobiphenyl-2,3-diol-1,2-dioxygenase of Pseudomonas sp. CA10 (Sato et al. 1997).

Sequence alignments with the corresponding subunit showed extensive sequence identity in the core of PmdA and over most of PmdB, and allowed key common features to be identified (Fig. 4). FldV, the smallest protein, appears to comprise just the core sequence of the $\alpha$ subunit, which includes two residues (Y90 and F103 in PmdA) corresponding to interactions with substrate in LigA (Fig. 4). Four conserved histidine residues $\left(\mathrm{H} 12, \mathrm{H} 59, \mathrm{H} 125\right.$ and $\mathrm{H} 197$ in $\left.\mathrm{PmdB}_{\mathrm{T}-2}\right)$ in the $\beta$ subunit are relevant, as is an asparagine $(\mathrm{N} 57$ in PmdB $_{\mathrm{T}-2}$ ). H12, N57 and H59 correspond to the ironbinding residues in the LigB-structure, while $\mathrm{H} 125$ and H197 correspond to residues that interact with polar and nonpolar regions of the aromatic substrate in $\operatorname{LigB}$ (Fig. 4). These histidines are found in four known motifs with the asparagine: SHXPA (H12 in PmdB) and NDHA (H59 in PmdB) in iron coordination, and DHG (H125 in PmdB) and GXSH (H197 in PmdB). These motifs are characteristic of the class III extradiol dioxygenases (Eltis and Bolin 1996; Peng et al. 1998). The consensus motif derived from extradiol dioxygenases of classes I and II (PROSITE PS00082) (Eltis and Bolin 1996) is absent.

A dendrogram (Fig. 5a), derived from the sequences of the $\alpha$ subunits of effectively heteromultimeric extradiol dioxygenases, shows that the seven sequences (Fig. 4) cluster together, but show some relationship to CarBa. A dendrogram of the $\beta$ subunits of all known representatives of extradiol oxygenases in class III shows four major lines, two of which are known by only one representative, $\mathrm{HpcB}$ and $\mathrm{CarBb}$. A third group has at least two representatives, MhpB and MpcI, whereas the fourth and currently largest group is that of the $\beta$ subunits of effectively heteromultimeric extradiol dioxygenases (Fig. 5b). The tight grouping of these $\beta$ subunits corresponds to the dendrogram for the $\alpha$ subunits (Fig. 5a). Class II oxygenases acting on monocyclic substrates diverge from those acting on biphenylic substrates (e.g. BphC-LB400). We wonder whether this subgrouping according to substrate (CarBab and $\mathrm{Li}$ $\mathrm{gAB})$ is present in class III.

Acknowledgements We are grateful to T. Tralau, who kindly did the Markov analyses, and to D. Schleheck, who did the lutidinic acid experiment. J.M. was funded by the Deutsche Forschungsgemeinschaft (to A.M.C. and J. Ruff) and BASF/BMBF, and M.A.P. by the Alexander von Humboldt Stiftung. Further funds were from the University of Konstanz and the Fonds der Chemischen Industrie.

\section{References}

Altschul SF, Madden TL, Schäffer AA, Zhang J, Zhang Z, Miller W, Lipman DJ (1997) Gapped BLAST and PSI-BLAST: a new generation of protein database search programs. Nucleic Acids Res 25:3389-3402

Arciero DM, Lipscomb JD (1986) Binding of ${ }^{17}$ O-labeled substrate and inhibitors to protocatechuate 4,5-dioxygenase-nitrosyl complex. J Biol Chem 261:2170-2178

Arciero DM, Lipscomb JD, Huynh BH, Kent TA, Münck E (1983) EPR and Mössbauer studies of protocatechuate 4,5-dioxygenase. Characterization of a new $\mathrm{Fe}^{2+}$ environment. J Biol Chem 258:14981-14991 
Bradford M (1976) A rapid and sensitive method for the quantitation of microgram quantities of protein utilizing the principle of protein-dye binding. Anal Biochem 72:248-254

Busse H-J, El-Banna T, Oyaizu H, Auling G (1992) Identification of xenobiotic-degrading isolates from the beta subclass of the Proteobacteria by a polyphasic approach including $16 \mathrm{~S}$ rRNA partial sequencing. Int J Syst Bacteriol 42:19-26

Contzen M, Bürger S, Stolz A (2001) Cloning of the genes for a 4sulphocatechol-oxidizing protocatechuate 3,4-dioxygenase from Hydrogenophaga intermedia $\mathrm{S} 1$ and identification of the amino acid residues responsible for the ability to convert 4sulphocatechol. Mol Microbiol 41:199-205

Cook AM (1987) Biodegradation of $s$-triazine xenobiotics. FEMS Microbiol Rev 46:93-116

Cook AM, Laue H, Junker F (1999) Microbial desulfonation. FEMS Microbiol Rev 22:399-419

Dagley S, Evans WC, Ribbons DW (1960) New pathways in the oxidative metabolism of aromatic compounds by microorganisms. Nature (Lond) 188:560-566

Dagley S, Geary PJ, Wood JM (1968) The metabolism of protocatechuate by Pseudomonas testosteroni. Biochem J 109:559-568

Eaton RW (2001) Plasmid-encoded phthaltate catabolic pathway in Arthrobacter keyseri 12B. J Bacteriol 183:3689-3703

Eltis LD, Bolin JT (1996) Evolutionary relationships among extradiol dioxygenases. J Bacteriol 178:5930-5937

Fersht AR (1999) Structure and mechanism in protein science. Freeman, New York

Hara H, Masai E, Miyauchi K, Katayama Y, Fukuda M (2003) Characterization of the 4-carboxy-4-hydroxy-2-oxoadipate aldolase gene and operon structure of the protocatechuate 4,5cleavage pathway genes in Sphingomonas paucimobilis SYK-6. J Bacteriol 185:41-50

Harayama S, Rekik M (1989) Bacterial aromatic ring-cleavage enzymes are classified in two different gene families. J Biol Chem 264:15328-15333

Harayama S, Rekik M (1993) Comparison of the nucleotide sequences of the meta-cleavage pathway genes of TOL plasmid pWW0 from Pseudomonas putida with other meta-cleavage genes suggests that both single and multiple nucleotide substitutions contribute to enzyme evolution. Mol Gen Genet 239:81-89

Harayama S, Kok M, Neidle EL (1992) Functional and evolutionary relationships among diverse oxygenases. Annu Rev Microbiol 46:565-601

Hirose J, Kimura N, Suyama A, Kobayashi A, Hayashida S, Furukawa K (1994) Functional and structural relationship of various extradiol aromatic ring-cleavage dioxygenases of Pseudomonas origin. FEMS Microbiol Lett 118:273-277

Jeanmougin F, Thompson JD, Gouy M, Higgins DG, Gibson TJ (1998) Multiple sequence alignment with Clustal X. Trends Biochem Sci 23:403-405

Junker F, Field JA, Bangerter F, Ramsteiner K, Kohler H-P, Joannou CL, Mason JR, Leisinger T, Cook AM (1994a) Oxygenation and spontaneous deamination of 2aminobenzenesulphonic acid in Alcaligenes sp. strain O-1 with subsequent meta ring cleavage and spontaneous desulphonation to 2-hydroxymuconic acid. Biochem J 300:429-436

Junker F, Leisinger T, Cook AM (1994b) 3-Sulphocatechol 2,3dioxygenase and other dioxygenases (EC 1.13.11.2 and EC 1.14.12.-) in the degradative pathways of 2-aminobenzenesulphonic, benzenesulphonic and 4-toluenesulphonic acids in Alcaligenes sp. strain O-1. Microbiology 140:1713-1722

Junker F, Saller E, Schläfli Oppenberg HR, Kroneck PMH, Leisinger T, Cook AM (1996) Degradative pathways for $p$-toluenecarboxylate and $p$-toluenesulfonate and their multicomponent oxygenases in Comamonas testosteroni strains PSB4 and T-2. Microbiology 142:2419-2427

Kennedy SIT, Fewson CA (1968) Enzymes of the mandelate pathway in bacterium N.C.I.B. 8250. Biochem J 107:497-506

Kersten PJ, Chapman PJ, Dagley S (1985) Enzymatic release of halogens or methanol from some substituted protocatechuic acids. J Bacteriol 162:693-697
Larimer FW, et al (2004) Complete genome sequence of the metabolically versatile photosynthetic bacterium Rhodopseudomonas palustris. Nat Biotechnol 22:55-61

Laue H, Cook AM (2000) Purification, properties and primary structure of alanine dehydrogenase involved in taurine metabolism in the anaerobe Bilophila wadsworthia. Arch Microbiol 174:162-167

Laue H, Field JA, Cook AM (1996) Bacterial desulfonation of the ethanesulfonate metabolite of the chloroacetanilide herbicide metazachlor. Environ Sci Technol 30:1129-1132

Laue H, Friedrich M, Ruff J, Cook AM (2001) Dissimilatory sulfite reductase (desulfoviridin) of the taurine- degrading, non-sulfate-reducing bacterium Bilophila wadsworthia RZATAU contains a fused DsrB-DsrD subunit. J Bacteriol $183: 1727-1733$

Locher HH, Leisinger T, Cook AM (1989) Degradation of $p$-toluenesulphonic acid via sidechain oxidation, desulphonation and meta ring cleavage in Pseudomonas (Comamonas) testosteroni T-2. J Gen Microbiol 135:1969-1978

Locher HH, Leisinger T, Cook AM (1991) 4-Sulphobenzoate 3,4dioxygenase: purification and properties of a desulphonative two-component enzyme system from Comamonas testosteroni T-2. Biochem J 274:833-842

Mampel J (2000) Transport und Regulationsphänomene beim Abbau von 4-Toluolsulfonat in Comamonas testosteroni. $\mathrm{PhD}$ Thesis, Department of Biology, University of Konstanz

Mampel J, Maier E, Tralau T, Ruff J, Benz R, Cook AM (2004) A novel outer-membrane anion channel (porin) as part of a putatively two-component transport system for 4-toluenesulphonate in Comamonas testosteroni T-2. Biochem J 383:91-99

Maruyama K, Shibayama T, Ichikawa A, Sakou Y, Yamada S, Sugisaki H (2004) Cloning and characterization of the genes encoding enzymes for the protocatechuate meta-degradation pathway of Pseudomonas ochraceae NGJ1. Biosci Biotechnol Biochem 68:1434-1441

Nakatsu CH, Straus NA, Wyndham RC (1995) The nucleotide sequence of the Tn 5271 3-chlorobenzoate 3,4-dioxygenase genes $(c b a A B)$ unites the class IA oxygenases in a single lineage. Microbiology 141:485-495

Neuhoff V, Arold N, Taube D, Ehrhardt W (1988) Improved staining of proteins in polyacrylamide gels including isoelectric focusing gels with clear background at nanogram sensitivity using Coomassie Brilliant Blue G-250 and R-250. Electrophoresis 9:255-262

Noda Y, Nishikawa S, Shiozuka K, Kadokura H, Nakajima H (1990) Molecular cloning of the protocatechuate 4,5-dioxygenase genes of Pseudomonas paucimobilis. J Bacteriol 172:2704-2709

Peng X et al. (1998) Cloning of a Sphingomonas paucimobilis SYK6 gene encoding a novel oxygenase that cleaves lignin-related biphenyl and characterization of the enzyme. Appl Environ Microbiol 64:2520-2527

Providenti MA, Mampel J, MacSween S, Cook AM, Wyndham RC (2001) Comamonas testosteroni BR6020 possesses a single genetic locus for extradiol cleavage of protocatechuate. Microbiology 147:2157-2167

Ribbons DW, Evans DC (1960) Oxidative metabolism of phthalic acid by soil pseudomonads. Biochem J 76:310-318

Saccone C, Lanave C, Pesole G, Preparata G (1990) Influence of base composition on quantitative estimates of gene evolution. Methods Enzymol 183:570-583

Saccone C, Lanave C, Pesole G (1993) Time and biosequences. Int J Syst Evol Microbiol 37:154-159

Sato S-I, Ouchiyama N, Kimura T, Nojiri H, Yamane H, Omori T (1997) Cloning of genes involved in carbazole degradation of Pseudomonas sp. strain CA10: nucleotide sequences of genes and characterization of meta-cleavage enzymes and hydrolase. J Bacteriol 179:4841-4849

Schägger H, von Jagow G (1987) Tricine-sodium dodecyl sulfatepolyacrylamide gel electrophoresis for the separation of proteins in the range from 1 to $100 \mathrm{kDa}$. Anal Biochem 166:368-379 
Schläfli Oppenberg HR, Chen G, Leisinger T, Cook AM (1995) Regulation of the degradative pathways from 4-toluenesulphonate and 4-toluenecarboxylate to protocatechuate in Comamonas testosteroni T-2. Microbiology 141:1891-1899

Spence EL, Kawamukai M, Sanvoisin J, Braven H, Bugg TDH (1996) Catechol dioxygenases from Escherichia coli (MhpB) and Alcaligenes eutrophus (MpcI): sequence analysis and biochemical properties of a third family of extradiol dioxygenases. $\mathbf{J}$ Bacteriol 178:5249-5256

Sugimoto K, Senda T, Aoshima H, Masai E, Fukuda M, Mitsui Y (1999) Crystal structure of an aromatic ring opening dioxygenase $\operatorname{Lig} \mathrm{AB}$, a protocatechuate 4,5-dioxygenase, under aerobic conditions. Structure (Lond) 7:953-965

Thurnheer T, Köhler T, Cook AM, Leisinger T (1986) Orthanilic acid and analogues as carbon sources for bacteria: growth physiology and enzymic desulphonation. J Gen Microbiol 132:1215-1220

Tralau T, Cook AM, Ruff J (2001) Map of the IncP1b plasmid pTSA encoding the widespread genes $(t s a)$ for $p$-toluenesulfonate degradation in Comamonas testosteroni T-2. Appl Environ Microbiol 67:1508-1516
Tralau T, Cook AM, Ruff J (2003a) An additional regulator, TsaQ, is involved with TsaR in regulation of transport during the degradation of $p$-toluenesulfonate in Comamonas testosteroni $\mathrm{T}$ 2. Arch Microbiol 180:319-326

Tralau T, Mampel J, Cook AM, Ruff J (2003b) Characterization of TsaR, an oxygen-sensitive LysR-type regulator for the degradation of p-toluenesulfonate in Comamonas testosteroni T-2. Appl Environ Microbiol 69:2298-2305

Vuilleumier S, Ivos N, Dean M, Leisinger T (2001) Sequence variation in dichloromethane dehalogenases/glutathione S-transferases. Microbiology 147:611-619

Wattiau P, Bastiaens L, van Herwijnen R, Daal L, Parsons JR, Renard ME, Springael D, Cornelis GR (2001) Fluorene degradation by Sphingomonas sp. LB126 proceeds through protocatechuic acid: a genetic analysis. Res Microbiol 152:861-872

Yun SH, Yun CY, Kim SI (2004) Characterization of protocatechuate 4,5-dioxygenase induced from $p$-hydroxybenzoatecultured Pseudomonas sp. K82. J Microbiol 42:152-155

Zabinski R, Münck E, Champion PM, Wood JM (1972) Kinetic and Mossbauer studies on the mechanism of protocatechuic acid 4,5-oxygenase. Biochemistry 11:3212-3219 